\title{
Premarital screening for genetic blood disorders - an integrated review on the knowledge and attitudes of Middle Eastern university students
}

\author{
Jansirani Natarajan(D) and Mickael Antoine Joseph ${ }^{*}$ (D)
}

\begin{abstract}
Background: Genetic blood disorders are prevalent in the Middle Eastern countries causing physical, mental, and economic handicap. Premarital screening (PMS) is actively implemented to reduce the burgeoning load of these disorders. Literature shows a low response rate for PMS in this region. This integrated review aims to identify the knowledge and attitude of university students on PMS, as they are at the verge of entering into marriage relationships.

Main body of the abstract: We systematically reviewed the electronic databases like MEDLINE, PubMed, CINAHL, and Scopus. Studies reporting about the knowledge and attitudes of Middle Eastern university students between 2010 and 2020 are included in the review. Twelve cross-sectional descriptive studies conducted in six countries met the inclusion criteria. Majority of the studies reported good level of knowledge on PMS among the university students, whereas not all of them agreed to undergo PMS due to various religious and cultural beliefs.

Short conclusion: We recommend massive health education programs at the higher secondary and university levels to create better awareness on PMS. To improve the attitude towards PMS, life cycle approach and support of the religious leaders could be sought.
\end{abstract}

Keywords: Knowledge, Attitude, University students, Premarital screening, Genetic screening, Middle East

\section{Background}

Autosomal recessive disorders like sickle cell disease (SCD), beta thalassemia, and other hemoglobinopathies are considered to be the most common genetic blood disorders in the world as well as in the Middle Eastern countries [1]. The incidence of children born with sickle cell disease is expected to increase globally by $30 \%$ by 2050 [2]. Available evidence suggests that congenital and genetic disorders are responsible for a large portion of mortality and handicap leading to poor quality of life of younger adults in this region. The incidence of hereditary blood disorders is intertwined with social, cultural,

\footnotetext{
*Correspondence: mickaelj@squ.edu.om; mickaelantoinejoseph@gmail.com Fundamentals and Administration Department, College of Nursing, Sultan Qaboos University, 123 Al Khoud Street, Muscat, Oman
}

and religious practices in Middle Eastern countries [3], which makes the management of the disorders more complicated. This creates a huge burden on the individuals and families as well as and the health care systems in these countries.

The Centre for Arab Genomic Studies based in United Arab Emirates has released a list of 906 genetic pathologies, which are endemic to Arab states. Some of the commonly prevalent genetic disorders are SCD, thalassemia, Tourette's syndrome, Wilson's disease, CharcotMarie-Tooth disease, mitochondrial encephalomyopathies, and Niemann-Pick disease [4]. Few studies have estimated that the highest prevalence rates of G6PD deficiency is ranging from 1\% among Egyptians to 11.55\% among Iranians [5]. On the other hand, the prevalence
Springer Open (c) The Author(s). 2021 Open Access This article is licensed under a Creative Commons Attribution 4.0 International License, which permits use, sharing, adaptation, distribution and reproduction in any medium or format, as long as you give appropriate credit to the original author(s) and the source, provide a link to the Creative Commons licence, and indicate if changes were made. The images or other third party material in this article are included in the article's Creative Commons licence, unless indicated otherwise in a credit line to the material. If material is not included in the article's Creative Commons licence and your intended use is not permitted by statutory regulation or exceeds the permitted use, you will need to obtain permission directly from the copyright holder. To view a copy of this licence, visit http://creativecommons.org/licenses/by/4.0/. 
of thalassemia among adult patients in the Middle East is reported to be $43.3 \%$ [6]. Regarding SCD, sickle cell hemoglobin (Hbs) is commonly seen in all Middle Eastern countries ranging from approximately 0.04 to $2.1 \%$ [7].

Premarital screening (PMS) and genetic counseling (GC) programs can identify and modify the health risk factors known to impact genetic disorders. PMS could be the most important way to prevent the abovementioned genetic blood disorders and many medical, psychological, and social marital problems [8]. PMS and GC programs are declared mandatory in eight Middle Eastern countries. They are free of cost to reduce the at-risk marriages and the prevalence of genetic disorders [9].

The worldwide epidemiologic burden of inherited erythrocyte disorders remains high according to the recent worldwide epidemiological report [10]. In the Arab region, a greater proportion of people (25-60\%) prefer consanguineous marriages [11]. Abortion is considered illegal in a majority of Arab countries, which necessitates the efforts to prevent the marriage of the disease carrier couples [12]. PMS can help the couple prepare themselves for marriage with proper premarital counseling giving them a better chance for a stable and satisfying marriage. According to the National Society of Genetic Counselors, "Genetic counseling is the process of helping people understand and adapt to the medical, psychological and familial implications of genetic contributions to disease" [13]. Though the PMS program has been widely implemented in these countries for approximately two decades, the success of the program lies in the awareness and attitudes towards PMS among the younger generation. Though Saudi Arabia has mandated the PMS program before marriage, $48 \%$ of the genetically incompatible couple have gone ahead with their marriage decision [14]. The population in Arab countries is characterized by large families, high maternal and paternal ages, and high levels of inbreeding [15]. A review conducted on the effectiveness of PMS and GC programs for beta thalassemia in Middle Eastern countries has revealed that a cancelation rate of $65 \%$ of at-risk marriage could not be achieved except in Iran, Turkey, and Iraq [9]. As an effort to identify the reason for the low response to this PMS program, we decided to review the studies conducted in this region on the aspects of knowledge and attitudes on PMS among the university students. Understanding the knowledge and attitude of this age group is crucial in developing strategies to create awareness and build positive attitudes towards PMS. University students are the target group as they are on the verge of making decisions about marriage.

\section{Main text}

\section{Aims and methods}

Whittemore and Knalf's integrated review process with five steps was used. The steps involved are identification of the problem to be studied, thorough literature search, appraisal of the quality of data, examination of the data, and presentation of conclusions [16]. A systematic literature search was conducted to identify the studies exploring the knowledge and attitudes on PMS among university students. The search included databases like MEDLINE, PubMed, Cumulative Index to Nursing and Allied Health Literature (CINAHL), and Scopus. Key words including knowledge, attitude, premarital screening, university students, and genetic blood disorders were used in the search. Inclusion criteria included quantitative studies that (a) assessed the knowledge of university students on PMS, (b) explored the attitude of university students towards PMS, (c) were published in peer-reviewed articles in English, (d) were published between 2010 and 2020, and (e) were from Middle Eastern countries. The final criterion was included due to international variation in culture and health policies. The search yielded 328 articles, and twelve of them met the inclusion criteria for review as depicted in Fig. 1.

\section{Measures}

Each article was evaluated based on the revised criteria of the American Association of Critical-Care Nurses $(\mathrm{AACN})$, which has six rating levels $[17,18]$. All included articles in our review were quantitative descriptive studies scoring " $\mathrm{C}$ " for level of evidence.

\section{Analysis of findings}

All the selected papers were reviewed carefully by two authors (JRN and MAJ) independently and finalized based on the inclusion criteria. JRN and MAJ extracted data from the literature, and discrepancies were resolved

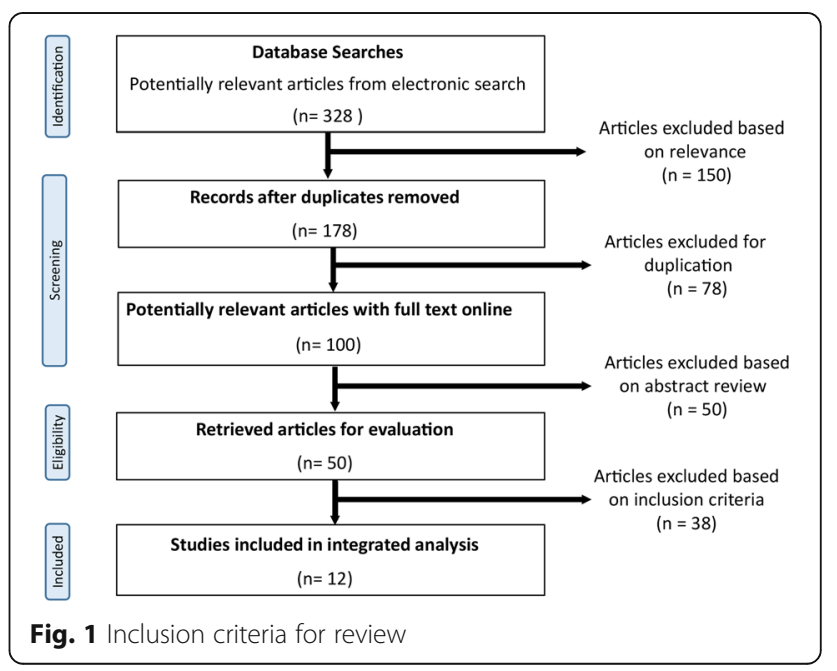


by discussion. Data was analyzed and synthesized using the matrix table suggested by [19], and the details of the studies (author, year of publication, country, purpose, methods, and findings) with level of evidence are provided in Table 1.

\section{Results}

A total of twelve studies conducted in six countries, including Kuwait, 1; Yemen, 1; Jordan, 1; Oman, 1; Egypt, 1 ; and KSA, 7, met the inclusion criteria for this review. All of the 12 studies were cross-sectional descriptive studies and have used researcher-developed selfreported questionnaires, as there are no valid standardized questionnaires available to assess the knowledge and attitude of PMS. The majority of the studies are conducted in the Middle Eastern countries where these hereditary disorders are commonly prevalent. The findings are discussed as narrative analysis under knowledge and attitudes on premarital screening of the university students in Table 2.

\section{Discussion}

The study has reviewed the knowledge and attitudes of Middle Eastern country university students on premarital screening. Regarding knowledge of the university students about PMS, eight of the studies reported good and adequate knowledge [14, 20-26]. One study reported fair level of knowledge [27], and two studies reported low level of knowledge [28-30]. One study even reported that female students had a good level of knowledge whereas male students had insufficient knowledge. Findings cannot be conclusive about the knowledge levels of the university students, as none of the studies used valid and reliable standardized questionnaires to assess the knowledge level on PMS. Even the educated Arab population has an extremely low level of genetic literacy, which poses a hindrance for genetic counseling [31]. Many Middle Eastern countries have realized the importance of PMS as a cost-effective measure to reduce the economic burden on society. Middle Eastern countries in general have good existing programs in reproductive and other primary health services where community genetic services could easily be integrated [32]. Massive health education starting from the higher secondary curriculum advancing to the college curriculum can increase knowledge levels. Education and examinations could be targeted towards unmarried male university students, which can facilitate them in making informed choices about unmarried females and consanguineous marriages.

Ten studies explored university students' attitudes towards PMS while two studies did not. Though the majority of the students from the reviewed studies were reported to have good and adequate knowledge, it is discouraging to note that not all of them agreed to undergo PMS due to various religious and cultural beliefs. Three of the reviewed studies reported negative or fair attitudes of university students related to PMS [21, 25, 27]. Participants of seven reviewed studies had positive attitudes towards PMS, and even held beliefs about making policies about it stronger [14, 20, 22-24, 29, 30]. One third of the participants in a study reported they would proceed with their marriage even if both partners tested positive for thalassemia, and they were unwilling to undergo PMS as it would affect their future marriage opportunities [22]. A higher level of female literacy, fear of hereditary blood disorders, urbanization, and better economic status of the families have caused a decrease in consanguineous marriages in Arab countries in recent years [33]. In a study conducted in Oman on South Batinah Governorate's adults, unwillingness to undergo PMS was associated with the following characteristics: female gender, lower education levels, younger age groups, and single populations [32]. Life cycle approaches are believed to attract a better holistic public response as a remedy to the barriers to PMS program success in the Middle East [9]. India and Canada successfully incorporated PMS into school health packages [34, 35]. Middle Eastern countries could follow this model of PMS incorporation at the higher secondary education level or make PMS mandatory for admission to the universities. Emphasis on structured health education on hereditary diseases and consanguineous marriages are needed in higher education levels.

Some participants believed that their fate is determined by God and therefore willing to accept the risk of bearing a sick child without undergoing PMS. This is similar to a study done in Oman among higher secondary school students who reported that they would accept the birth of children with genetic blood disorders as God's will [36]. Though Islam promotes healthy marriage and the role of counseling, $90 \%$ of the couples detected as carriers in KSA proceeded with their marriages. A Nigerian study conducted among religious leaders had reported good knowledge and positive attitudes towards PMS for sickle cell disease [37], and a similar study can be conducted in Middle Eastern countries to understand the viewpoints of religious leaders. Individuals with incompatible genes expressed a fear of stigma associated with the carrier status. They frequently face familial pressures with consanguineous marriages. These problems could be reduced with community health education with the support of religious authorities [38]. There is a need for intensification of health education campaigns among youth, and religious leaders could be involved to clarify and correct misconceptions about PMS [22]. 
Table 1 Summary of the articles with author, country, year, participants, methods, instruments, study purpose, and main findings

\begin{tabular}{|c|c|c|c|c|c|c|c|c|}
\hline $\begin{array}{l}\text { SL. } \\
\text { NO. }\end{array}$ & $\begin{array}{l}\text { Author, } \\
\text { year, and } \\
\text { country }\end{array}$ & Participants & Methods & Instrument & Study purpose & Main findings & $\begin{array}{l}\text { Major } \\
\text { aspects }\end{array}$ & $\begin{array}{l}\text { Level of } \\
\text { evidence }\end{array}$ \\
\hline 1 & $\begin{array}{l}\text { Ibrahim } \\
\text { et al., 2011, } \\
\text { Jeddah, } \\
\text { KSA }\end{array}$ & $\begin{array}{l}1563 \text { students from } \\
\text { all faculties of KAU }\end{array}$ & $\begin{array}{l}\text { Cross- } \\
\text { sectional } \\
\text { study, } \\
\text { multistage } \\
\text { stratified } \\
\text { random } \\
\text { sample }\end{array}$ & $\begin{array}{l}\text { Researcher- } \\
\text { developed } \\
\text { questionnaire }\end{array}$ & $\begin{array}{l}\text { The present study was } \\
\text { conducted to assess } \\
\text { knowledge and attitudes } \\
\text { of unmarried female } \\
\text { students in King Abdul- } \\
\text { Aziz University (KAU) } \\
\text { towards premarital } \\
\text { screening (PMS) programs. }\end{array}$ & $\begin{array}{l}\text { Students' knowledge about } \\
\text { the program was generally } \\
\text { low ( } 80 \% \text { had poor scores). } \\
\text { Regarding attitude, almost } \\
\text { all students }(99.0 \%) \text { agreed } \\
\text { on the importance of PMS. }\end{array}$ & $\mathrm{K}, \mathrm{A}$ & $C$ \\
\hline 2 & $\begin{array}{l}\text { Al Kindi } \\
\text { et al., 2012, } \\
\text { Muscat, } \\
\text { Oman }\end{array}$ & $\begin{array}{l}590 \text { unmarried } \\
\text { Omani students of } \\
\text { both genders }\end{array}$ & $\begin{array}{l}\text { Cross- } \\
\text { sectional } \\
\text { study }\end{array}$ & $\begin{array}{l}\text { Researcher- } \\
\text { developed } \\
\text { questionnaire }\end{array}$ & $\begin{array}{l}\text { The aim of this study was } \\
\text { to explore the knowledge } \\
\text { and attitudes of Sultan } \\
\text { Qaboos University } \\
\text { students towards } \\
\text { premarital screening } \\
\text { programs. }\end{array}$ & $\begin{array}{l}\text { Most of the participants } \\
(79 \%) \text { were aware of the } \\
\text { availability of premarital } \\
\text { screening program in } \\
\text { Oman. The vast majority of } \\
\text { participants }(92 \%) \text { thought } \\
\text { it was important to carry } \\
\text { out premarital screening } \\
\text { and agreed to do it. }\end{array}$ & $\mathrm{K}, \mathrm{A}$ & C \\
\hline 3 & $\begin{array}{l}\text { Ebtisam } \\
\text { and Khalil, } \\
\text { 2014, KSA }\end{array}$ & $\begin{array}{l}120 \text { King Saud } \\
\text { University female } \\
\text { students }\end{array}$ & $\begin{array}{l}\text { Cross- } \\
\text { sectional } \\
\text { study, } \\
\text { random } \\
\text { sample }\end{array}$ & $\begin{array}{l}\text { Researcher- } \\
\text { developed } \\
\text { self-reported } \\
\text { questionnaire }\end{array}$ & $\begin{array}{l}\text { This study aimed at } \\
\text { assessing the knowledge, } \\
\text { beliefs, and behavior of } \\
\text { KSU female students in } \\
\text { Riyadh, regarding the } \\
\text { national premarital } \\
\text { screening program (PMS). }\end{array}$ & $\begin{array}{l}\text { Most of the King Saud } \\
\text { University's female students } \\
\text { had fair knowledge and fair } \\
\text { behavior towards premarital } \\
\text { screening. }\end{array}$ & $K, A$ & C \\
\hline 4 & $\begin{array}{l}\text { Farahat } \\
\text { et al., 2014, } \\
\text { Egypt }\end{array}$ & $\begin{array}{l}345 \text { students from } \\
\text { Menoufia University } \\
\text { faculties in Shebin } \\
\text { Elkom City }\end{array}$ & $\begin{array}{l}\text { Cross- } \\
\text { sectional } \\
\text { study }\end{array}$ & $\begin{array}{l}\text { Researcher- } \\
\text { developed } \\
\text { self-reported } \\
\text { questionnaire }\end{array}$ & $\begin{array}{l}\text { The aim of the study was to } \\
\text { assess the knowledge and } \\
\text { attitudes of Menoufia } \\
\text { University students } \\
\text { towards premarital care } \\
\text { (PMC). }\end{array}$ & $\begin{array}{l}\text { The results of this study } \\
\text { clearly showed that } 75.1 \% \\
\text { of the participants were } \\
\text { aware of the presence of } \\
\text { PMC services, and the } \\
\text { participants' attitudes } \\
\text { towards PMC were } \\
\text { favorable (53.9\%). }\end{array}$ & $\mathrm{K}, \mathrm{A}$ & $C$ \\
\hline 5 & $\begin{array}{l}\text { Al Khaldi } \\
\text { et al., 2016, } \\
\text { Amman, } \\
\text { Jordan }\end{array}$ & $\begin{array}{l}542 \text { students from } \\
\text { four universities } \\
\text { (two public and } \\
\text { two private } \\
\text { universities) located } \\
\text { in North Jordan }\end{array}$ & $\begin{array}{l}\text { Cross- } \\
\text { sectional } \\
\text { study }\end{array}$ & $\begin{array}{l}\text { Researcher- } \\
\text { developed } \\
\text { self-reported } \\
\text { questionnaire }\end{array}$ & $\begin{array}{l}\text { This aimed to assess the } \\
\text { knowledge and attitudes } \\
\text { of university students in } \\
\text { North Jordan towards the } \\
\text { mandatory National } \\
\text { Premarital Thalassemia } \\
\text { Screening Program } \\
\text { implemented in } 2004 \text {. }\end{array}$ & $\begin{array}{l}\text { Respondents had adequate } \\
\text { knowledge of and positive } \\
\text { attitudes towards the } \\
\text { premarital screening } \\
\text { program. }\end{array}$ & $\mathrm{K}, \mathrm{A}$ & C \\
\hline 6 & $\begin{array}{l}\text { Al Nood } \\
\text { et al., 2016, } \\
\text { Yemen }\end{array}$ & $\begin{array}{l}516 \text { students of the } \\
\text { Faculty of Medicine } \\
\text { and Health } \\
\text { Sciences, Sana'a } \\
\text { University }\end{array}$ & $\begin{array}{l}\text { Cross- } \\
\text { sectional } \\
\text { study }\end{array}$ & $\begin{array}{l}\text { Researcher- } \\
\text { developed } \\
\text { self-reported } \\
\text { questionnaire }\end{array}$ & $\begin{array}{l}\text { To assess the knowledge } \\
\text { and attitudes of Sana } \\
\text { University medical } \\
\text { students towards } \\
\text { premarital screening (PMS). }\end{array}$ & $\begin{array}{l}\text { Most of the respondents } \\
(92 \%) \text { knew that PMS } \\
\text { reduces hereditary and } \\
\text { sexually transmitted } \\
\text { diseases, believed that it is } \\
\text { important to carry out, and } \\
\text { agreed to do it. Making } \\
\text { PMS mandatory and legal } \\
\text { prevention of marriage in } \\
\text { case of positive results were } \\
\text { accepted by } 82 \% \text { and } 62 \% \\
\text { of the respondents, } \\
\text { respectively. }\end{array}$ & $\mathrm{K}, \mathrm{A}$ & $C$ \\
\hline 7 & $\begin{array}{l}\text { Alghamadi } \\
\text { et al., 2016, } \\
\text { KSA }\end{array}$ & $\begin{array}{l}320 \text { students of } \\
\text { King Saud } \\
\text { University }\end{array}$ & $\begin{array}{l}\text { Cross- } \\
\text { sectional } \\
\text { study } \\
\text { multistage } \\
\text { sampling } \\
\text { method }\end{array}$ & $\begin{array}{l}\text { Researcher- } \\
\text { developed } \\
\text { self-reported } \\
\text { questionnaire }\end{array}$ & $\begin{array}{l}\text { To assess knowledge of } \\
\text { premarital screening and } \\
\text { their relation to the socio- } \\
\text { demographic background } \\
\text { of male university students } \\
\text { in Riyadh City. }\end{array}$ & $\begin{array}{l}\text { Students of higher } \\
\text { academic level showed a } \\
\text { significantly higher level of } \\
\text { knowledge. Knowledge of } \\
\text { male university students } \\
\text { about the PMS program } \\
\text { was insufficient in some } \\
\text { areas. }\end{array}$ & K & $C$ \\
\hline 8 & Enezi and & 809 students of & Cross- & Researcher- & The aim of the study was to & $92 \%$ were aware of & $\mathrm{K}, \mathrm{A}$ & $C$ \\
\hline
\end{tabular}


Table 1 Summary of the articles with author, country, year, participants, methods, instruments, study purpose, and main findings (Continued)

\begin{tabular}{|c|c|c|c|c|c|c|c|c|}
\hline $\begin{array}{l}\text { SL. } \\
\text { NO. }\end{array}$ & $\begin{array}{l}\text { Author, } \\
\text { year, and } \\
\text { country }\end{array}$ & Participants & Methods & Instrument & Study purpose & Main findings & $\begin{array}{l}\text { Major } \\
\text { aspects }\end{array}$ & $\begin{array}{l}\text { Level of } \\
\text { evidence }\end{array}$ \\
\hline & $\begin{array}{l}\text { Mitra, 2017, } \\
\text { Kuwait }\end{array}$ & Kuwait University & $\begin{array}{l}\text { sectional } \\
\text { study }\end{array}$ & $\begin{array}{l}\text { developed } \\
\text { self-reported } \\
\text { questionnaire }\end{array}$ & $\begin{array}{l}\text { determine the level of } \\
\text { knowledge, attitudes and } \\
\text { satisfaction among } \\
\text { university students } \\
\text { regarding premarital } \\
\text { screening programs. }\end{array}$ & $\begin{array}{l}\text { premarital screening, and } \\
85 \% \text { showed positive } \\
\text { attitudes towards PMS. }\end{array}$ & & \\
\hline 9 & $\begin{array}{l}\text { Melaiabri } \\
\text { et al., 2017, } \\
\text { KSA }\end{array}$ & $\begin{array}{l}380 \text { students of Taif } \\
\text { University }\end{array}$ & $\begin{array}{l}\text { Cross- } \\
\text { sectional } \\
\text { study }\end{array}$ & $\begin{array}{l}\text { Researcher- } \\
\text { developed } \\
\text { self-reported } \\
\text { questionnaire }\end{array}$ & $\begin{array}{l}\text { To investigate the } \\
\text { knowledge, attitudes, and } \\
\text { practices of Taif University } \\
\text { students towards the } \\
\text { national PMS program. }\end{array}$ & $\begin{array}{l}\text { Most participants (97.4\%) } \\
\text { were aware of the PMS } \\
\text { program and }(82.9 \%) \text { were } \\
\text { willing to change their } \\
\text { decision to marry in the } \\
\text { case of receiving } \\
\text { incompatible results. } \\
\text { Moreover, the majority of } \\
\text { the participants ( } 91.8 \%) \\
\text { demanded the } \\
\text { implementation of a law } \\
\text { that prohibits incompatible } \\
\text { marriages. }\end{array}$ & $\mathrm{K}, \mathrm{A}$ & $C$ \\
\hline 10 & $\begin{array}{l}\text { Moussa } \\
\text { et al., 2018, } \\
\text { KSA }\end{array}$ & $\begin{array}{l}640 \text { students of } \\
\text { seven colleges of } \\
\text { Hail University }\end{array}$ & $\begin{array}{l}\text { Cross- } \\
\text { sectional } \\
\text { study }\end{array}$ & $\begin{array}{l}\text { Researcher- } \\
\text { developed } \\
\text { self-reported } \\
\text { questionnaire }\end{array}$ & $\begin{array}{l}\text { To detect the degree of } \\
\text { knowledge and attitudes } \\
\text { of the female university } \\
\text { students of Hail University } \\
\text { towards the national } \\
\text { mandatory premarital } \\
\text { screening program (NPMS). }\end{array}$ & $\begin{array}{l}\text { Majority of the participants } \\
\text { were aware of the } \\
\text { availability of the program } \\
(75.5 \%) \text { and }(76.2 \%) \text { knew } \\
\text { that it was obligatory to } \\
\text { complete it before } \\
\text { marriage. }\end{array}$ & K & $C$ \\
\hline 11 & $\begin{array}{l}\text { Qahtani } \\
\text { et al., 2019, } \\
\text { KSA }\end{array}$ & $\begin{array}{l}541 \text { students of } \\
\text { King Khalid } \\
\text { university, Nurjan }\end{array}$ & $\begin{array}{l}\text { Cross- } \\
\text { sectional } \\
\text { study } \\
\text { Two stage } \\
\text { stratified } \\
\text { cluster } \\
\text { sampling } \\
\text { technique }\end{array}$ & $\begin{array}{l}\text { A researcher- } \\
\text { developed } \\
\text { self- } \\
\text { administered } \\
\text { questionnaire }\end{array}$ & $\begin{array}{l}\text { This study aimed to assess } \\
\text { university students' } \\
\text { knowledge, attitudes, and } \\
\text { practice of premarital } \\
\text { counseling (PMC) in King } \\
\text { Khalid University. }\end{array}$ & $\begin{array}{l}\text { Nearly three out of four } \\
\text { students had a good } \\
\text { awareness level regarding } \\
\text { PMC. Most of the students } \\
\text { had a positive attitude } \\
\text { towards PMS and their } \\
\text { readiness to adopt the } \\
\text { counseling before marriage. }\end{array}$ & $K, A$ & $C$ \\
\hline 12 & $\begin{array}{l}\text { Alhowiti, } \\
\text { et al, 2019, } \\
\text { KSA }\end{array}$ & $\begin{array}{l}437 \text { students of } \\
\text { Tabuk University, } \\
\text { KSA }\end{array}$ & $\begin{array}{l}\text { Cross- } \\
\text { sectional } \\
\text { study }\end{array}$ & $\begin{array}{l}\text { A researcher- } \\
\text { developed } \\
\text { self- } \\
\text { administered } \\
\text { questionnaire }\end{array}$ & $\begin{array}{l}\text { To assess the level of } \\
\text { knowledge and the } \\
\text { attitudes among Saudi } \\
\text { Tabuk University students } \\
\text { regarding premarital } \\
\text { screening programs. }\end{array}$ & $\begin{array}{l}\text { Slightly less than half of the } \\
\text { students }(48.3 \%) \text { had } \\
\text { sufficient knowledge } \\
\text { regarding premarital } \\
\text { screening. Almost two } \\
\text { thirds of the students } \\
(69.8 \%) \text { had a positive } \\
\text { attitude towards premarital } \\
\text { screening. }\end{array}$ & $\mathrm{K}, \mathrm{A}$ & C \\
\hline
\end{tabular}

$A$ attitude, $K$ knowledge

Table 2 Themes from the review on PMS

\begin{tabular}{ll}
\hline Themes & Findings \\
\hline Knowledge about PMS (12 studies) & Eight studies have reported good and adequate level of knowledge [14, 20-26] \\
& One study has reported fair level of knowledge [27] \\
& Two studies have reported low level of knowledge [28-30] \\
& Three studies have reported negative of fair attitude towards PMS [21, 25, 27] \\
Attitude towards PMS (10 studies) & Seven studies have reported positive attitudes towards PMS [14, 20, 22-24, 29, 30]
\end{tabular}




\section{Limitations}

All of the 12 studies reviewed relied upon the researcher-developed self-reported questionnaires. The questionnaires were developed and reviewed by experts in most of the cases. Future studies could observe the practice of PMS tests among university students along with their knowledge and attitudes. Only studies published in English were included, which might have resulted in the omission of valuable studies in other languages.

\section{Conclusion}

Various factors have contributed to the inadequate information on the extent to which these genetic blood disorders in the Middle Eastern region pose health and economic burdens; this exposes the importance of sustainable research activities in this area. The findings of this review have opened up new areas of health education needs among the yet-to-be-married couples (university students) regarding genetic blood disorders. Health education strategies involving family members, lawmakers, and religious leaders could enhance the younger Middle Eastern population's compliance to PMS. Mass outreach programs through various social media platforms is the need of the hour to create awareness among the younger generation and to alleviate the burden of these genetic blood disorders on the individuals and society in the Middle East. A very exciting phase for reducing the genetic burden in the human population in this region of the world has begun, and it is hoped that this mission will succeed.

\section{Abbreviations \\ CINAHL: Cumulative Index to Nursing and Allied Health Literature; SCD: Sickle cell disease; GS: Genetic counseling; G6PD: Glucose-6-phosphate dehydrogenase; PMS: Premarital screening}

\section{Acknowledgements}

Not applicable

\section{Authors' contributions}

JRN conceived and designed the study. JRN and MAJ performed the database search. JRN wrote the manuscript, drafted the studies in table form, and discussed the results. MAJ revised the literature search and reviewed and critically revised the review before submission for spelling and grammar. Both authors have read and approved the final manuscript.

\section{Funding}

No funding was obtained for the review.

Availability of data and materials

Not applicable

\section{Declarations}

Ethics approval and content to participate

Not applicable

\section{Consent for publication}

Not applicable

\section{Competing interests}

The authors declare that they have no competing interest.

Received: 26 March 2021 Accepted: 16 June 2021

Published online: 30 June 2021

\section{References}

1. Williams TN, Weatherall DJ (2012) World distribution, population genetics, and health burden of the hemoglobinopathies. Cold Spring Harb Perspect Med 2(9):a011692. https://doi.org/10.1101/cshperspect.a011692

2. Piel FB, Hay SI, Gupta S, Weatherall DJ, Williams TN (2013) Global burden of sickle cell anaemia in children under five, 2010-2050: modelling based on demographics, excess mortality, and interventions. PLoS Med 10(7): e1001484. https://doi.org/10.1371/journal.pmed.1001484

3. Chawla S, Singh RK, Lakkakula BV, Vadlamudi RR (2017) Attitudes and beliefs among high-and low-risk population groups towards $\beta$-thalassemia prevention: a cross-sectional descriptive study from India. J Comm Genet 8(3):159-166. https://doi.org/10.1007/s12687-017-0298-4

4. Abu-Shaheen, A., Munshi, H., Nofal, A., Abdelmoety, D. A., Riaz, M., \& AlFayyad, I. (2019). Epidemiology of sickle cell disease in Gulf Cooperation Council countries: a systematic review. Available at SSRN 3429912.

5. Usanga EA, Ameen R (2000) Glucose-6-phosphate dehydrogenase deficiency in Kuwait, Syria, Egypt, Iran, Jordan and Lebanon. Hum Hered 50(3):158-161. https://doi.org/10.1159/000022906

6. Abu-Shaheen A, Heena H, Nofal A, Abdelmoety DA, Almatary A, Alsheef M et al (2020) Epidemiology of thalassemia in Gulf Cooperation Council countries: a systematic review. Biomed Res Int 2020

7. Bailey M, Gibbs M, Dani N, Mendell A, Thompson M (2019) Burden of illness of sickle cell disease in countries of the Middle East: a systematic literature review. American Society of Hematology, Washington, DC

8. Balci Yl, Ergin A, Polat A, Atilgan T, Utku U, Koyuncu H (2014) Thalassemia premarital screening program: public view, what has been done, what needs to be done? Int J Hematol Oncol 29(4):247-252

9. Saffi M, Howard N (2015) Exploring the effectiveness of mandatory premarital screening and genetic counselling programmes for $\beta$ thalassaemia in the Middle East: a scoping review. Public Health Genom 18(4):193-203. https://doi.org/10.1159/000430837

10. Lippi G, Mattiuzzi C (2020) Updated worldwide epidemiology of inherited erythrocyte disorders. Acta Haematol 143(3):196-203. https://doi.org/10.11 $59 / 000502434$

11. Gowans LJ, Cameron-Christie S, Slayton RL, Busch T, Romero-Bustillos M, Eliason S et al (2019) Missense pathogenic variants in KIF4A affect dental morphogenesis resulting in X-linked taurodontism, microdontia and densinvaginatus. Front Genet 10:800. https://doi.org/10.3389/fgene.2019.00800

12. Kulwicki AD (2021) People of Arab heritage. In: Textbook for transcultural health care: a population approach. Springer, pp 251-276

13. Resta R, Biesecker BB, Bennett RL, Blum S, Hahn SE, Strecker MN et al (2006) A new definition of genetic counseling: National Society of Genetic Counselors' Task Force report. J Genet Couns 15(2):77-83. https://doi.org/1 0.1007/s10897-005-9014-3

14. Melaibari M, Shilbayeh S, Kabli A (2017) University students' knowledge, attitudes, and practices towards the national premarital screening program of Saudi Arabia. J Egypt Public Health Assoc 92(1):36-43. https://doi.org/1 0.21608/EPX.2018.6648

15. Al-Gazali L, Hamamy H (2014) Consanguinity and dysmorphology in Arabs. Hum Hered 77(1-4):93-107. https://doi.org/10.1159/000360421

16. Whittemore R, Knafl K (2005) The integrative review: updated methodology. J Adv Nurs 52(5):546-553. https://doi.org/10.1111/j.1365-2648.2005.03621.x

17. Adachi-Mejia AM, Drake KM, MacKenzie TA, Titus-Ernstoff L, Longacre MR, Hendricks KM, Beach ML, Dalton MA (2010) Perceived intrinsic barriers to physical activity among rural mothers. J Women's Health 19(12):2197-2202. https://doi.org/10.1089/jwh.2009.1879

18. Armola RR, Bourgault AM, Halm MA, Board RM, Bucher L, Harrington L, Heafey C, Lee RK, Shellner PK, Medina J, for the 2008-2009 Evidence-Based Practice Resource Work Group of the American Association of Critical-Care Nurses (2009) Upgrading the American association of critical-care nurses' evidence-leveling hierarchy. Am J Crit Care 18(5):405-409. https://doi.org/1 $0.4037 / a j c c 2009170$

19. Garrard J (2020) Health sciences literature review made easy 
20. Al Kindi R, Al Rujaibi S, Al Kendi M (2012) Knowledge and attitude of university students towards premarital screening program. Oman Med J 27(4):291-296. https://doi.org/10.5001/omj.2012.72

21. Al-Enezi K, Mitra AK (2017) Knowledge, attitude, and satisfaction of university students regarding premarital screening programs in Kuwait. Eur $J$ Environ Public Health 1(2):07

22. Alkhaldi SM, Khatatbeh MM, Berggren VE, Taha HA (2016) Knowledge and attitudes toward mandatory premarital screening among university students in North Jordan. Hemoglobin 40(2):118-124. https://doi.org/10.3109/036302 69.2015.1135159

23. Al-Nood HA, Al-Akmar MM, Al-Erynai EF (2016) Knowledge and attitudes of Sana'a University medical students towards premarital screening. Yemeni J Med Sci 10:39-46

24. Al-Qahtani FS, Alfahad MI, Alshahrani AMM, Almalih HS, Al-Malki ASQ, Alshehri TK et al (2019) Perception of premarital counseling among King Khalid University students. J Family Med Prim Care 8(8):2607-2611. https:// doi.org/10.4103/jfmpc.jfmpc_364_19

25. Farahat TM, Shaheen HME, Mohamed HM, Mohaseb MMM (2014) Knowledge and attitude of students in Menoufia University, Shebin Elkom city toward premarital care in 2012. Menoufia Med J 27(2):347

26. Moussa S, Al-Zaylai F, Al-Shammari B, Al-Malaq K, Al-Shammari SR, AlShammari TF (2018) Knowledge and attitude towards premarital screening and genetic counseling program among female university students, Hail region, Saudi Arabia. Int J Med Health Res 4(1):1-6

27. Khalil E, Abdelkader SM, Alsaeed MD, Alshahrany NM (2014) Knowledge, beliefs and behavior intention about premarital screening among King Saud University female students in Riyadh. Sch J Appl Med Sci 2(5E):1797-1805

28. Alghamdi AM, Alqadheb AF, Alzahrani AM, Aldhahri AS, Alsharif ZM (2016) Knowledge of premarital screening among male university students in Riyadh, Saudi Arabia. Int J Med Sci Public Health 5(4):735. https://doi.org/10. 5455/ijmsph.2016.21112015222

29. Ibrahim NKR, Al-Bar H, Al-Fakeeh A, Al Ahmadi J, Qadi M, Al-Bar A et al (2011) An educational program about premarital screening for unmarried female students in King Abdul-Aziz University, Jeddah. J Infect Public Health 4(1):30-40. https://doi.org/10.1016/j.jiph.2010.11.001

30. Alhowiti A, Shaqran T (2019) Premarital screening program knowledge and attitude among Saudi University students in Tabuk city 2019. Int J Med Res Health Sci 8(11):75-84

31. Gharaibeh N (2009) Disability in Arab societies is a challenging subject for several reasons. Praeger Westport, CT

32. Al-Farsi OA, Al-Farsi YM, Gupta I, Ouhtit A, Al-Farsi KS, Al-Adawi S (2014) A study on knowledge, attitude, and practice towards premarital carrier screening among adults attending primary healthcare centers in a region in Oman. BMC Public Health 14(1):380. https://doi.org/10.1186/14 71-2458-14-380

33. Tadmouri GO, Nair P, Obeid T, Al Ali MT, Al Khaja N, Hamamy HA (2009) Consanguinity and reproductive health among Arabs. Reprod Health 6(1):17. https://doi.org/10.1186/1742-4755-6-17

34. Cousens NE, Gaff CL, Metcalfe SA, Delatycki MB (2010) Carrier screening for beta-thalassaemia: a review of international practice. Eur J Hum Genet 18(10):1077-1083. https://doi.org/10.1038/ejhg.2010.90

35. Thiyagarajan A, Bhattacharya S, Sharma N, Srivastava A, Dhar DK (2019) Need for a universal thalassemia screening programme in India? A public health perspective. J Family Med Prim Care 8(5):1528

36. Al-Kindi RM, Kannekanti S, Natarajan J, Shakman L, Al-Azri Z, Al-Kalbani NI (2019) Awareness and attitude towards the premarital screening programme among high school students in Muscat, Oman. Sultan Qaboos Univ Med J 19(3):e217

37. Abubakar SB, Abdulqadir I, Magaji BA, Sanusi N, Ibrahim F, Maiturare M (2019) Knowledge, attitude and perception of traditional and religious leaders on pre-marital screening for sickle cell disease in Sokoto. Int J Med Public Health 9(2):36-41. https://doi.org/10.5530/ijmedph.2019.2.10

38. Belhoul KM, Abdulrahman M, Alraei RF (2013) Hemoglobinopathy carrier prevalence in the United Arab Emirates: first analysis of the Dubai Health Authority premarital screening program results. Hemoglobin 37(4):359-368. https://doi.org/10.3109/03630269.2013.791627

\section{Publisher's Note}

Springer Nature remains neutral with regard to jurisdictional claims in published maps and institutional affiliations.

\section{Submit your manuscript to a SpringerOpen ${ }^{\circ}$ journal and benefit from:}

- Convenient online submission

- Rigorous peer review

- Open access: articles freely available online

High visibility within the field

- Retaining the copyright to your article

Submit your next manuscript at $\boldsymbol{\nabla}$ springeropen.com 